Physical Therapy Journal of Indonesia (PTJI) 2021, Volume 2, Number 2: 46-49

E-ISSN : 2722-6034; P-ISSN : 2722-0125

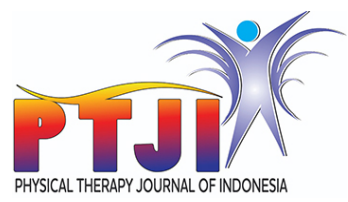

\title{
The Correlation of Cognitive and Functional Ability among Elderly
}

\author{
Gede Budhi Artha Yoga ${ }^{1 *}$, I. A. Pascha Paramurthi ${ }^{1}$, I Putu Astrawan ${ }^{1}$
}

\section{ABSTRACT}

Background: Elderly is someone who has reached the age of 60 years and over. Increasing age will experience changes in the structure and physiology of the brain, which will affect cerebral blood flow and metabolism, which will affect the decline in cognitive function. The cognitive impairment will have a negative impact on the process of thinking, remembering, and processing information.

Objective: To determine the relationship between cognitive and functional abilities in the elderly.

Methods: A cross-sectional study was conducted on April 2021 with a population of elderly who met the inclusion and exclusion criteria. The elderly selected by purposive sampling obtained 52 samples. Cognitive measurement using MMSE and functional ability with IADL Lawton. Data were analyzed using a computer's Somers' $d$ test to determine the relationship between cognitive and functional abilities.

Results: Analysis of the relationship between cognitive and functional abilities of 52 elderly using Somers'd showed a p-value of $0.001 \quad(p<0.005)$ which reported a significant relationship between cognitive and functional abilities.

Conclusion: there was a relationship between cognitive and functional abilities in the elderly.

Keywords: Elderly, Cognitive, Functional Abilities

Cite this Article: Yoga, G.B.A., Paramurthi, I.A.P., Astrawan, I.P. 2021. The Correlation of Cognitive and Functional Ability among Elderly. Physical Therapy Journal of Indonesia 2(2): 46-49. D0l: 10.51559/ptji.v2i2.34

'Physiotherapy Study Program, College of Health Sciences, Universitas Bali Internasional, Bali, Indonesia

\section{*Corresponding to:} Gede Budhi Artha Yoga, Physiotherapy Study Program, College of Health Sciences, Universitas Bali Internasional; yogakicik@gmail.com
Received : 2021-08-08 Accepted : 2021-11-24 Published: 2021-12-02

\section{BACKGROUND}

The elderly is a population group aged 60 years or more. A person is generally categorized as elderly if they are over 60 years old, but this definition varies greatly depending on socio-cultural, physiological and chronological aspects. ${ }^{1}$ Aging is a process of slowly disappearing the ability of tissues to repair themselves or replace and maintain their normal functions so that they cannot survive infection and improve the damage suffered. ${ }^{2}$ The elderly population in Indonesia is increasing from time to time. The increase in the number of ages of the elderly follows with the decrease of the body immune system of the elderly. The elderly will experience physical changes in the sensory system, musculoskeletal system, cardiovascular and respiratory systems, urinary system, reproductive system, and the nervous system undergoes anatomic changes and progressive atrophy in the nerve fibres of the elderly. Ageing also causes a decrease in perception, sensory and motor responses in the central nervous system (CNS), and a decrease in proprioceptive receptors; this occurs because the central nervous system in the elderly undergoes morphological and biochemical changes. ${ }^{3}$

Cognitive function is a mental process in acquiring knowledge or intellectual abilities, including thinking, remembering, understanding, planning, and implementing. ${ }^{4}$ Cognitive disorders can be suffered by both young and old age groups, causing cognitive abilities to decline slowly over time. ${ }^{4}$ One of the health problems that can affect the quality of life of the elderly is cognitive impairment, where cognitive impairment will cause several conditions that have a negative impact. In the process of thinking, remembering, and processing the information they get, this results in a decrease in the functional abilities of the elderly such as planning monthly shopping, using cellphones, being able to go somewhere, preparing food, doing homework, washing clothes, arranging medicines, and manage finances. This study was conducted to determine the relationship between cognitive and functional abilities in the elderly. ${ }^{5}$

\section{METHODS}

\section{Research design}

This research is an analytic observational study with a cross-sectional design, which is done by taking samples from the population according to the selection criteria.

\section{Place and time of research}

We conducted the study in Banjar Tegal Narungan, Sobangan Village, Mengwi District, Badung Regency, and data collection was carried out in 
March - April 2021.

\section{Population and Sample}

The population in this study were the elderly in Banjar Tegal Narungan, Sobangan Village, Mengwi District, Badung Regency, Bali-Indonesia. Where sampling with the following criteria:(a) Elderly aged 60 - 74 years. (b) The elderly can understand or understand what is conveyed by the researcher. $c$. Good general condition, vital signs within normal limits. (d) Willing to become a respondent is indicated by agreeing to the informed consent. (e) Do not have psychiatric disorders such as dementia, delirium, amnestic and severe head trauma. (f) There is no history of neurological diseases such as stroke and Parkinson's. (g) There is no history of injury or fracture to the upper and lower extremities.

\section{Cognitive Independent Variables}

Cognitive measurement using the mini-mental state examination (MMSE) instrument, which is used to measure cognition in the elderly MMSE, there are 11 questions, the description of the MMSE is a structured scale consisting of 30 points grouped into seven categories: orientation concerning time (year, season, month, day and date), orientation to place (country, province, district), registration (repeat quickly three words), attention and concentration (sequentially reducing the number 7 , starting from number 100 , or spelling the word "revelation" backwards), recall (recall three words that have been repeated previously), language (name two objects, repeat sentences, read aloud and understand a sentence, write sentences and follow commands three steps), and visual construction (copying images). ${ }^{6}$

The MMSE score is based on correct items; a lower score indicates poor performance and severe cognitive impairment. The total score is 0-30 (perfect performance). The first recommended MMSE threshold score of 24 or 25 has good sensitivity and specificity for detecting dementia. A study claimed this score is too low, especially in people with higher educational status. ${ }^{6}$

\section{Dependent Variable Functional ability}

The instrument used to measure functional ability in the elderly is the instrumental activity of daily living (IADL) Lawton questionnaire. There are eight questions of the IADL Lawton questionnaire that will be given to the elderly that will lead to specification activities about the routines of daily life, such as using the telephone, taking care of all shopping needs independently, planning or preparing meals independently, maintaining the cleanliness of the house itself, washing clothes themselves, travelling independently, being responsible for taking medication in the correct dose on time, and managing finances independently. On a scale of 8 for women and a scale of 5 for men. ${ }^{7}$

\section{Data analysis}

The data of this study were analyzed by the SPSS v.26.0 for windows. Data on the characteristics of the research sample including age, gender, and occupation are presented in a descriptive table. The univariate descriptive analysis in this study is a general analysis of frequency and percentage. We categorized the cognitive domain of MMSE and the functional ability of IADL as the three variables (i.e. normal, possibly impaired, and impaired) and two variables (i.e. normal and poor functions), respectively.

We used the Somers'd Test analysis to analyze the relationship between the independent (cognitive domain of MMSE) and dependent (functional ability of IADL) variables. We considered the Somers' correlation test significant if the $P$-value $<0.05$, there is no significant correlation with the $P$-value $>0.05$.

\section{RESULTS}

\section{Characteristics of Research Subjects}

Based on the sample size formula, the number of subjects in this study was 52 people. Table 1 shows that there were 28 female respondents (53.85\%). Based on age, 21 respondents $(40.4 \%)$ were being 65-69 years old. Based on the jobs, there were housewives, farmers, and workshop work by 12 (23.2\%), $38(73.0 \%)$, and $2(3.8 \%)$, respectively.

Table 1 shows that the respondents who have a cognitive impairment were 22 respondents (42.3\%), the normal cognitive category were 17 respondents (32.7\%), and the probable cognitive impairment were 13 respondents (25\%). In addition, $71.2 \%$ of respondents (37 people) had a poor functional ability, and $28.8 \%$ (15 people) had a normal functional ability.

\section{Hypothesis test}

Table 2 shows 22 (42.3\%) respondents with cognitive impairment with poor functional abilities, $15(28.8 \%)$ respondents with normal cognitive with good functional abilities, $13(25.0 \%)$ participants with possible cognitive impairment with poor functional ability and $2(3.8 \%)$ respondents with normal cognitive category with poor functional capacity. The Somers' d test found a significant relationship between cognitive conditions with the functional abilities of the elderly, with a p-value of 0.001 . 
Table 1. Characteristics of the subjects

\begin{tabular}{lcc}
\hline \multicolumn{1}{c}{ Characteristics of Respondents } & Frequency & Percentage \\
\hline Age & 19 & 36.5 \\
$60-64$ & 21 & 40.4 \\
$65-69$ & 12 & 23.1 \\
$70-74$ & & \\
Sex & 28 & 53.85 \\
Women & 24 & 46.15 \\
Men & & \\
Occupation & 12 & 23.2 \\
Household & 38 & 73.0 \\
Farmer & 2 & 3.8 \\
Workshop worker & & \\
Cognitive status & 17 & 32.7 \\
Normal & 13 & 25.9 \\
Possible cognitive impairment & 22 & 42.3 \\
Cognitive impairment & & \\
Functional ability & 15 & 28.8 \\
Good & 37 & 71.2 \\
Bad & 52 & 100 \\
\hline$\quad$ Total & & \\
\hline
\end{tabular}

Table 2. The relationship between cognitive status and functional ability

\begin{tabular}{lccccccc}
\hline \multirow{2}{*}{ Cognitive status } & \multicolumn{9}{c}{ Functional Ability } & & \multirow{2}{*}{ Total } & \multirow{P}{*}{-value } \\
\cline { 2 - 5 } & \multicolumn{2}{c}{ Normal } & \multicolumn{2}{c}{ Poor } & & & \\
\cline { 2 - 6 } & $\boldsymbol{n}$ & $\%$ & $\boldsymbol{n}$ & $\%$ & $\boldsymbol{N}$ & $\%$ & \\
\hline Normal & 15 & 28.8 & 2 & 3.8 & 17 & 32.7 & 0.0001 \\
$\begin{array}{l}\text { Possible cognitive } \\
\text { impairment }\end{array}$ & 0 & 0.0 & 13 & 25.0 & 13 & 25.0 & \\
Cognitive Disorder & 0 & 0.0 & 22 & 42.3 & 22 & 42.3 & \\
\hline Total & 15 & 28.8 & 37 & 71.2 & 52 & 100.0 & \\
\hline
\end{tabular}

\section{DISCUSSION}

\section{Characteristics of Respondents}

Characteristics based on age in this study has a relationship to the cognitive and functional abilities of the elderly. Functional ability decrease in the elderly affects cerebral blood flow and metabolism, which affect cognitive decline. ${ }^{8}$ Some decreases will follow a person's age in adulthood in body tissue to cause reduced muscle ability and other organ functions. The gradual decrease in the ability of body tissues will cause interference in carrying out various daily activities. ${ }^{9}$

Characteristics of respondents based on gender indicate that there are more female respondents, amounting to 28 people and male respondents as many as 24 people. Gender of female respondents compared to men who have a higher cognitive risk in women. Women have the opportunity to develop cognitive disorders such as Alzheimer's, dementia, and delirium. Women have a menopause phase in life that has its role in increasing the risk of cognitive conditions such as Alzheimer's disease, dementia, and delirium. Women also often have problems remembering time, place, and day so that in their daily physical functional activities, the elderly often need the help of others. ${ }^{10}$

Elderly people still working tend to have a better quality of life than those who do not work. By working, one's life will be more meaningful in daily activities, especially cognitive function will be more awake. Not much different from cognitive, work can also support functional activities in the elderly where work is related to a person's functional activities and affects their well-being. Someone who works tends to have a better quality of life than those who do not work because by working, carrying out functional activities regularly, and being supported by high education, a person's ability to carry out his role will also increase. This will increase self-esteem and quality of life where someone who works still has a source of income, gets better support from the work environment and will minimize role conflicts that occur due to changes in physical conditions in the elderly. ${ }^{11}$

\section{Relationship between Cognitive and Functional Abilities}

From the results of this study, the elderly in this study mostly have poor cognitive might be correlated with the ages as the absolute risk for cognitive function disorders. Increasing age is associated with structural and functional changes that affect cerebral blood flow and metabolism with added restrictions on elderly physical activity during the Corona Virus Disease 19 (Covid-19) pandemic. The ageing process results in changes in the elderly. Changes or setbacks experienced by the elderly are cognitive changes. Cognitive is a person's belief about something obtained from the thought process. The process carried out is to gain knowledge through remembering, analyzing, understanding, assessing, imagining, and speaking. ${ }^{12}$ The effects of changes in muscle structure can lead to a decrease in the number and size of muscle fibres, an increase in connective tissue and fat tissue in the muscles. In addition to physiological changes, the elderly also experience morphological changes. Morphological changes in the musculoskeletal system can result in changes in muscle size that shrink and loss of strength, flexibility, and endurance due to decreased activity and ageing. ${ }^{13}$

A person's physiological health can affect the ability to participate in daily activities. For example, the nervous system collects, transmits, and manages information from the environment. The musculoskeletal system coordinates with 
the nervous system to respond to sensory input through movement. Disturbances in this system, for example, due to illness or traumatic injury, can interfere with the fulfilment of daily activities. The most common complaint experienced by the elderly is pain, both joint pain and muscle pain. ${ }^{14}$ This research is also in line with the study of Reny Chairir et al. (2017) showed a positive and significant relationship between cognitive function and physical functional abilities of the elderly. ${ }^{15}$ The better the condition of cognitive function, the better the physical functional ability in the elderly.

\section{CONCLUSION}

The study results showed a significant relationship between cognitive and functional abilities in the elderly in Banjar Tegal Narungan, Sobangan Village, Mengwi District, Badung Regency.

\section{CONFLICT OF INTEREST}

The author states there is no potential conflict of interest in connection with the research, authorship and or publication.

\section{ACKNOWLEDGEMENT}

The authors would like to thank the heads of Sobangan Village, Mengwi District, Badung Regency for giving permission and information during this study period. And thanks to the supervisor for the guidance and support during this study. This study received no funding from any institution.

\section{REFERENCES}

1. Fatimah F. Merawat Manusia Lanjut Usia. Jakarta: Transinfo Media. 2010

2. Nugroho HW, editor Komunikasi dalam keperawatan gerontic 2009: EGC.
3. Azizah LM. Keperawatan lanjut usia. 2011.

4. Santoso H, Ismail H. Memahami krisis lanjut usia: BPK Gunung Mulia; 2009.

5. Deary IJ, Corley J, Gow AJ, Harris SE, Houlihan LM, Marioni RE, et al. Age-associated cognitive decline. Br Med Bull. 2009;92(1):135-52.

6. Folstein MF, Folstein SE, McHugh PR. "Mini-mental state": a practical method for grading the cognitive state of patients for the clinician. J Psychiatr Res. 1975;12(3):18998.

7. Lawton MP, Brody EM. Assessment of older people: selfmaintaining and instrumental activities of daily living. The gerontologist. 1969;9(3_Part_1):179-86.

8. Coresa T, Ngestiningsih D. Gambaran fungsi kognitif pada lansia di unit rehabilitasi sosial pucang gading semarang. Diponegoro Medical Journal (Jurnal Kedokteran Diponegoro). 2017;6(1):114-9.

9. Utomo B. Hubungan antara kekuatan otot dan daya tahan otot anggota gerak bawah dengan kemampuan fungsional lanjut usia: UNS (Sebelas Maret University); 2010.

10. Lestari W, Ngestiningsih D. Hubungan Antara Status Kognitif dengan Status Fungsional Lanjut Usia Panti Wredha di Semarang. Jurnal Kedokteran Diponegoro. 2013;2(1):137874.

11. Sapti A. Perkembangan Usia Mempengaruhi Kekuatan Otot Punggung pada Orang Dewasa Usia 40-60 Tahun. Gaster. 2018;16(1):1-5.

12. Ramdhani N. Sikap dan perilaku: dinamika psikologi mengenai perubahan sikap dan perilaku. Yogyakarta: Universitas Gadjah Mada. 2008.

13. Koampa MM, Bidjuni H, Onibala F. Hubungan Antara Tingkat Stres Dengankemandirian Pada Orang Tualanjut Usia Di Desatombasian Atas Kecamatankawangkoan Barat. Jurnal Keperawatan. 2015;3(2).

14. Pinilih SS, Astuti RT, Rini DR. Hubungan Antara Lifestyle Dengan Fungsi Kognitif Pada Lansia. Journal of Holistic Nursing Science. 2018;5(1):25-35.

15. Chaidir R, Amelia D, Syafril E. Hubungan Faktor-Faktor Dengan Kemampuan Fungsional Fisik Lansia Wanita. 'Afiyah. 2017;4(2).

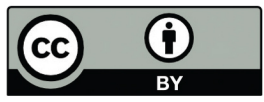

This work is licensed under a Creative Commons Attribution 